Al-Manhaj: Jurnal Hukum dan Pranata Sosial Islam

Vol. : : 2 (2), 2020, 195-215

P-ISSN : 2686-1607

E-ISSN : 2686-4819

\title{
PERHITUNGAN ARAH KIBLAT MASJID MENGGUNAKAN THEODOLIT DI KEBONSARI MADIUN
}

\author{
Aro Qodam Arrasyid, Kadenun \\ Institut Agama Islam Sunan Giri Ponorogo \\ email: arrasyid@gmail.com, kadenunhasan@gmail.com
}

Abstract: Qibla direction is the direction that Muslims go to in carrying out worship, especially prayer. The determination of the Qibla direction in the Fatma Zahra, Al-Falah, and Baitul Muttaqin Mosques used to still use simple tools. Whereas in this day and age, all modern equipment already exists. From the differences of time, the writer is interested in studying the calculation of Qibla direction by using theodolite, by determining the direction of Qibla before using theodolite and after using theodolite. This research uses quantitative methods by collecting observational study data, interviews, and documentation to related parties. The primary source is data from interviews and direct research in the field. While the secondary data is taken from books, journals and theses related to this research. From the results of this study that the Mosques studied have not yet led to a perfect Qibla. The qibla direction in each Mosque is as follows: Qibla direction in Fatma Zahra Mosque is 65035 '5.64", in Al-Falah Mosque is 650 34' 21.17 ", and in Baitul Muttaqin Mosque is 65035 '2.5". from the direction of the Qibla which was originally the Fatma Zahra Mosque 610 05'11.28 ", AlFalah Mosque 67009 '43.34", and the Baitul Muttaqin Mosque 70057 '35.00'.

Keywords: Calculation, Qibla direction, Theodolite 
Abstrak: Arah kiblat merupakan arah yang dituju umat Islam dalam melaksanakan ibadah khususnya shalat. Penentuan arah kiblat di masjid Fatma Zahra, Al-Falah, dan Baitul Muttaqin dulunya masih menggunakan alat yang sederhana. Sedangkan pada zaman sekarang ini, sudah zamannya modern semua peralatan canggih sudah ada. Dari perbedaan zaman tersebut penulis tertarik untuk mengkaji perhitungan arah kiblat dengan menggunakan alat theodolit, dengan menentukan arah kiblat sebelum menggunakan alat theodolit dan setelah menggunakan alat theodolit. Penelitian ini menggunakan metode kuantitatif dengan mengumpulkan data bersifat Studi Observasi, wawancara, dan dokumentasi kepada pihak-pihak terkait. Sebagai sumber primernya yaitu data dari hasil wawancara dan penelitian langsung di lapangan. Sedangkan data sekundernya diambil dari buku, jurnal, dan tesis yang berkaitan dengan penelitian ini. Dari hasil penelitian ini bahwa masjid-masjid yang diteliti belum mengarah ke kiblat secara sempurna. Adapun arah kiblat di masing-masing masjid adalah sebagai berikut: Arah kiblat di masjid Fatma Zahra ialah 650 35' 5.64",di masjid Al-Falah ialah 650 34' 21.17", dan di masjid Baitul Muttaqin ialah 650 $35^{\prime} 2.5^{\prime \prime}$. dari arah kiblat yang semula masjid Fatma Zahra 610 05'11.28', masjid Al-Falah 67009' 43.34", dan masjid Baitul Muttaqin 70057'35.00".

Kata Kunci: Perhitungan, Arah kiblat, Theodolit

\section{PENDAHULUAN}

Arah kiblat merupakan arah yang di tuju oleh umat Islam dalam melaksanakan ibadah khususnya shalat, yaitu menghadap ke arah ka'bah di Masjidil Haram. Kata arah Kiblat terdiri dua kata yaitu : kata arah berarti jurusan, tujuan, dan maksud lain memberi arti jarak terdekat yang diukur melalui lingkaran besar pada permukaan bumi dan yang lain artinya jihad, syathrah dan 
Aro Qodam Arrasyid \& Kadenun, Perhitungan Arah Kiblat Masjid Menggunakan ... 197 azimuth. Sedangkan kata Kiblat berarti Ka'bah yang terletak di dalam Masjidil Haram Kota Makkah.

Para ulama sepakat menghadap ke arah kiblat merupakan syarat sahnya shalat, maka kaum muslimin wajib menghadap ke arah kiblat dalam melakukan ibadah shalat. Dengan demikian, arah kiblat adalah suatu arah ( kiblat di Makkah) yang wajib dituju oleh umat Islam ketika ibadah shalat. Pada hakikatnya kiblat adalah suatu arah yang menyatukan arah segenap umat Islam dalam melaksanakan shalat, tetapi titik arah itu sendiri bukanlah obyek yang disembah oleh umat Islam dalam melaksanakan shalat. Yang menjadi objek yang dituju oleh umat Islam dalam melaksakan shalat itu tidak lain hanyalah Allah SWT.1

Dari paparan di atas, jelas bahwa sangatlah penting untuk mengetahui arah kiblat dengan benar. Dalam kitab-kitab fiqih disebutkan bahwa menghadap kiblat merupakan salah satu syarat sahnya shalat. Hal ini sesuai dengan sabda Nabi Muhammad SAW : Ishaq bin Mansur menceritakan kepada kita, Abdullah bin Umar menceritakan kepada kita, Ubaidullah menceritakan dari Sa'id bin Ali Sa'id al-Magburiyyi dari Abi Hurairah r.a berkata Rasulullah SAW. Besabda : "Bila kamu hendak shalat maka sempurnakanlah wudlu lalu menghadap kiblat kemudian bertakbirlah".(H.R Bukhari). ${ }^{2}$

Akhir-akhir ini kita sering mendengar isu tentang pergeseran lempeng bumi yang berpengaruh terhadap arah kiblat,

1 Farid, "Penerapan Algoritma Jean Meus dalam Pengukuran Arah Kiblat dengan Theodolit", Tesis UIN Walisongo, 2012.

2 Abu Abdillah Muhammad bin Ismail Al-Bukhari, Shahih Bukhari (Beirut: Dar Al-Fikr), 130. 
tetapi itu semua masih belum kontrofersi belum ada kepastian. Jadi, penulis masih yakin kalau arah kiblat itu masih tetap belum ada pergeseran sekalipun banyak isu yang mengabar bahwa arah kiblat saat ini sudah bergeser. Oleh karena itu, mengetahui secara pasti tentang hukum menghadap kiblat dan cara menentukan arah tersebut menjadi sangat penting untuk diketahui secara tepat agar ibadah shalat yang dilakukan dapat secara meyakinkan telah menghadap kiblat.

Dari paparan di atas, maka artikel ini ingin mengkaji lebih lanjut mengenai arah kiblat yang sebenarnya setelah menggunakan alat theodolit dan arah kiblat sebelum menggunakan alat theodolite di Masjid Fatma Zahra, Masjid Al-Falah, dan Masjid Baitul Muttaqin Kec. Kebonsari Madiun. Penelitian ini merupakan penelitian lapangan atau field research dengan menggunakan tiga teknik pengumpulan data yaitu teknik wawancara, observasi, dan dokumentasi terhadap obyek kajian. Sementara analisis data dalam penelitian ini yaitu menggunakan teknis analisis data kuantitatif yakni dengan metode perhitungan falak mengenai arah kiblat di tiga masjid tersebut.

\section{PENGERTIAN ARAH KIBLAT}

Secara etimologi, kata kiblat berasal dari bahasa Arab "qiblatun", yang berarti menghadap atau arah, dan yang dimaksud dengan arah di sini adalah arah ke Ka'bah. ${ }^{3}$ Dalam ungkapan Arab dikatakan "ma likalamihi qiblatun ai jihatun" artinya ucapan tidak 2008), 123.

3 Muhammad Murtadho, Ilmu Falak Praktis (Malang: UIN Malang Press, 
Aro Qodam Arrasyid \& Kadenun, Perhitungan Arah Kiblat Masjid Menggunakan ... 199 mempunyai kiblat, maksudnya tidak mempunyai arah "aina qiblatuka" artinya ke mana arahmu? "Wa ma lahu qiblatun wa la dairatun" artinya dia tidak memiliki arah mengenai permasalahannya. ${ }^{4} \mathrm{Al}-\mathrm{Manawi}$ (w. 1031/1621) dalam kitabnya atTaufik 'ala Muhimmat at-Ta'arif menjelaskan bahwa "kiblat" adalah segala sesuatu yang ditempatkan di muka, ${ }^{5}$ atau sesuatu yang kita menghadap kepadanya. Jadi secara harfiah kiblat mempunyai pengertian arah ke mana orang menghadap. Oleh karena itu, Ka'bah disebut sebagai kiblat, karena ia menjadi arah yang kepadanya orang harus menghadap dalam mengerjakan shalat. ${ }^{6}$

Menurut Ulama Fiqh 'ala al-Madzahib al-Arba'ah karangan Abdurrahman al-Jaziri, halaman 194, mengatakan bahwa arah kiblat adalah arah ka'bah atau wujud ka'bah, maka barang siapa yang berada di dekat ka'bah tidak sah shalatnya kecuali dengan menghadap ke wujud ka'bah dan orang yang jauh dari ka'bah (tidak melihat), maka baginya berijtihad untuk menghadap kiblat (ke arah kiblat). ${ }^{7}$

Kiblat yang mempunyai pengertian arah, berarti identik dengan kata jihah dan syathrah, yang dalam bahasa latin dikenal dengan istilah Azimut. Dalam wacana Ilmu Falak, azimut diartikan

4 Tim Majelis Tarjih dan Tajdid PP Muhammadiyah, Pedoman Hisab Muhammadiyah (Yogyakarta: Majelis Tarjih dan Tajdid PP Muhammadiyah, 2009), 25.

${ }^{5}$ Al-Manawi, at-Taufik 'ala Muhimmat at-Ta'arif (Beirut: Dar al-Fikri alMu'asir, Damaskus: Dar al-Fikr, 1410 H), 5-172.

${ }^{6}$ Al-Manawi, 26.

7 Umar Salim, Panduan Ilmu Falak (Ponorogo: Madrasah Miftahul Huda Mayak, 2013), 7. 
sebagai arah yang posisinya diukur dari titik utara sepanjang lingkaran horizon se-arah jarum jam. ${ }^{8}$

Adapun arah kiblat menurut terminologis, para Ulama berfariasi memberikan definisi tentang arah kiblat, antara lain:

1. Abdul Aziz Dahlan: Kiblat sebagai bangunan ka'bah atau arah yang dituju kaum Muslimin dalam melaksanakan ibadah.

2. Harun Nasution: Kiblat sebagai arah untuk menghadap pada waktu shalat.

3. Mochtar Efendi: Kiblat sebagai arah shalat, arah Ka'bah di kota Makkah.

4. Ensiklopedi Indonesia: Kiblat (arah Ka'bah). Islam mengartikan kiblat ialah jurusan ke arah Makkah, khususnya ke Ka'bah, diambil kaum muslimin dalam melaksanakan ibadah shalat. Selain Ka'bah juga Masjid Aqsha pernah menjadi kiblat shalat selama 16 bulan sesudah hijrah ke Madinah, kemudian dipalingkan ke Ka'bah sesuai permohonan Nabi Muhammad SAW.

5. Arah kiblat dilihat dari jarak yang ditempuh, menurut Muhyidin Khazin adalah arah atau jarak terdekat sepanjang lingkaran besar yang melewati Ka'bah (Makkah) dengan tempat kota yang bersangkutan.

Dari beberapa definisi mengenai arah kiblat, maka dapat disimpulkan bahwa arah kiblat adalah arah menuju Ka'bah yang wajib dituju oleh umat Muslim dalam mengerjakan shalat dan ibadah lainnya yang letaknya di tengah-tengah Masjidil Haram. 
Aro Qodam Arrasyid \& Kadenun, Perhitungan Arah Kiblat Masjid Menggunakan ... 201

Bagi mereka yang berada di dekat Ka'bah tidak sah baginya jika tidak menghadap ke wujud Ka'bah, sedangkan bagi mereka yang jauh dari Ka'bah, maka mereka berijtihad untuk menghadap ke arah atau jurusan kiblat yakni kota Makkah.

\section{HUKUM MENGHADAP KIBLAT}

Para Ulama telah membuat konsensus (ijma') yang menetapkan bahwa menghadap kiblat adalah salah satu syarat sahnya shalat khauf, shalat sunnah di atas kendaraan atau perahu. Hal ini telah ditetapkan dalam al-Qur'an dan as-Sunnah. Para Ulama sependapat bahwa orang yang mengerjakan shalat itu wajib menghadap ke arah Masjidil Haram. Kiblat orang Islam ketika shalat, baik orang itu melihat Ka'bah maupun orang itu jauh dari Ka'bah. Kiblatnya adalah syathrah Ka'bah, yakni arah jurusan Ka'bah yang tepat.

Menghadap kiblat merupakan syarat sahnya shalat, tetapi seseorang yang shalat boleh juga tidak menghadap kiblat, yaitu dalam tiga perkara; (1) Ketika sangat takut, umpamanya dalam keadaan yang sangat hebat, atau lari dari kejaran binatang buas dan lain-lainnya. (2) Ketika mengerjakan shalat sunnah di atas kendaraan saat perjalanan, kecuali ketika mengucapkan takbiratul ihram hendaknya menghadap kiblat. Jika ia sujud, hendaklah ia lebih merendahkan kepalanya dari pada ruku', sementara arah kiblatnya adalah mengikuti arah kendaran. (3) Sangat lemah dan sukar menghadap ke arah kiblat, umpamanya ketika malam gelap 
gulita dalam perjalanan, serta pedoman telah hilang, seperti hari hujan yang sangat lebat atau badai di laut. ${ }^{9}$

\section{PENDAPAT ULAMA TENTANG HUKUM MENGHADAP KIBLAT}

Semua Ulama Madzhab sepakat bahwa Ka'bah itu adalah kiblat bagi orang yang dekat dan dapat melihatnya, tetapi mereka berbeda pendapat tentang kiblat bagi orang yang jauh dan tidak dapat melihatnya.

1. Hanafiyah

Jika ada seseorang yang hendak melakukan shalat dan dia tidak tahu arah kiblat, sedangkan ia berada di negara muslim, maka ada beberapa kriteria:

a. Apabila negara tersebut ada mihrab masjid yang tergolong kuno yang dibuat oleh para shahabat, tabi'in, dan sebagainya, maka ia wajib mengikuti arah mihrab tersebut.

b. Apabila tidak ada, maka wajib bertanya dengan tiga syarat:

1) Ia tidak bertanya kepada orang tuli (tidak dapat mendengar);

2) Orang tidak mengarah ke arah kiblat;

3) Orang yang bisa diterima kesaksiannya.

c. Apabila tidak mendapatkan jawaban, maka wajib mengadakan penelitian atau menurut ijtihadnya yang semaksimal mungkin.

2. Malikiyah

9 Ibnu Mas'ud dan Zainal Abidin, Fiqh Madzhab Syafi'i (Bandung: CV Pustaka Setia, 2000), 154. 
Aro Qodam Arrasyid \& Kadenun, Perhitungan Arah Kiblat Masjid Menggunakan ... 203

Arah kiblat bagi orang yang tinggal di Makkah atau sekitarnya, maka kiblatnya adalah wajib menghadap ke bangunan Ka'bah atau 'ainul Ka'bah secara tepat, dengan meluruskan seluruh badannya pada Ka'bah dan tidak cukup baginya sekedar menghadap ke utara. Tetapi bagi mereka yang sedang shalat dan tidak melihat 'ainul Ka'bah, maka mereka wajib menghadap ke arah Ka'bah (jihadul Ka'bah).

3. Syafi'iyah

Dapat digolongkan menjadi tiga kriteria:

a. Jika ia mengetahui arah kiblat, maka tidak boleh bertanya kepada siapapun. Bagi orang yang buta dan ia mampu menyentuh tembok masjid untuk mengetahui arah kiblat, maka ia tidak boleh bertanya.

b. Seseorang dapat bertanya pada seseorang yang dapat dipercaya dan mengetahui arah kiblat, baik dengan kompas, kutub, mihrab (baik yang kuno maupun yang kebanyakan dipakai orang yang shalat), akan tetapi mihrab yang terdapat di mushalla kecil, hanya dipakai sebagian orang saja.

c. Berijtihad apabila tidak ada orang yang dapat dipercaya untuk ditanya atau menggunakan alat-alat yang dipakai untuk dijadikan pedoman dalam menentukan arah kiblat.

\section{Hanabilah}

Orang yang mengetahui arah kiblat dan berada di negara yang ada mihrabnya, maka dia wajib mengikuti mihrab dan tidak boleh berpaling dari mihrabnya. Mereka yang tidak menghadap 
mihrab, maka harus bertanya kepada seseorang dan mengikuti orang itu walaupun dia mengetahui dengan adanya petunjukpetunjuk. Apabila waktunya sempit untuk meneliti sendiri, maka wajib berusaha sesuai dengan ijtihadnya. Dan jika tidak menemukan mujtahid, maka ia berhati-hati dalam berijtihad serta mengerjakan sesuai dengan ijtihadnya.

Al-Alamah al-Qurthubi berkata dalam tafsirnya al-Jami' li Ahkam al-Qur'an, sebagai berikut: Ulama berbeda pendapat tentang orang yang tidak melihat Ka'bah dalam shalatnya, apakah wajib menghadap secara persis ke tubuh Ka'bah atau hanya menghadap ke arahnya saja? Di antara mereka ada yang berpendapat “wajib” menghadap persis ke wujud Ka'bah ('ain alKa'bah); Ibnu Arabi berkata: pendapat ini lemah, karena merupakan paksaan melakukan sesuatu yang tidak mungkin dapat dilaksanakan. Dan di antara pendapat mereka ada yang mengatakan "cukup menghadap ke arahnya saja". Inilah pendapat yang benar, karena tiga segi:

a. Karena pendapat itulah yang mungkin bisa dilaksanakan sebagai suatu beban (agama).

b. Karena itulah yang diperintahkan (Allah) dalam al-Qur'an alKarim "maka palingkanlah mukamu ke arah Masjidil Haram".

c. Karena para Ulama juga berhujjah (beralasan) dengan shalat jama'ah yang shafnya panjang, hal itu diketahui secara pasti bahwa tidak dapat menjangkau lebarnya 'ain al-Ka'bah (lebar Ka'bah 20 hasta lebih sedikit). 
Aro Qodam Arrasyid \& Kadenun, Perhitungan Arah Kiblat Masjid Menggunakan ... 205

\section{TEKNIK MENGHADAP KIBLAT}

Shalat Fardlu, shalat Sunnah atau ibadah shalat lainnya, semuanya harus menghadap kiblat, lalu timbul pertanyaan bagi kita yang jauh dari Ka'bah, bagaimana cara menghadap muka ke Ka'bah? Rasulullah memberi tuntunan dalam sebuah hadits, yaitu (hadist ini hasan shahih): Nabi pada waktu itu berada di Madinah, sehingga Makkah berada di antara Timur dan Barat. Sabda Nabi Saw. yang lain, yaitu: Hadits ini menegaskan bagi yang melihat Ka'bah, kiblatnya adalah Ka'bah, bagi yang tinggal di kota Makkah, kiblatnya adalah Masjidil Haram. Sedangkan orang-orang yang tinggal jauh dari Makkah, maka kiblatnya adalah menghadap ke arah kota Makkah.

Kewajiban ini berlaku untuk siapa saja yang melakukan shalat Fardlu, sehingga orang yang tidak mengetahui di mana kiblat itu berada, baik karena dia tidak mengetahui ilmu falak, maupun tidak tahu karena bingung, maka dia harus bertanya, jika dia mau shalat, maka harus bertanya di mana dia sedang menghadap. Bila orang itu ingin membangun masjid, maka ia harus tahu ke mana masjid itu dihadapkan, bahwa ia tidak boleh mengerjakan shalat sebelum ia berijtihad untuk mencari kiblat, karena kiblat sebagai lambang persatuan dan kesatuan arah bagi orang yang beragama Islam, Oleh karenanya, kesatuan arah itu harus selalu diusahakan setepat-tepatnya. Al-Azhar dan Hamka berpendapat bahwa: Dari uraian-uraian beliau tentang ijtihad menentukan arah kiblat, beliau menegaskan bahwa: "Sampai di antara kamu yang harus belajar ilmu falak yang pada mulanya 
sengaja untuk mengetahui hal kiblat saja, sampai menjadi ilmu yang luas". 10

\section{TEORI MENENTUKAN ARAH KIBLAT}

Menentukan azimut kiblat (sudut B) haruslah disediakan data-data: lintang tempat dan bujur tempat yang dijadikan markaz perhitungan (misalnya Ponorogo). Sesudah itu disiapkan pula segitiga yang titik-titik sudutnya terdiri dari kutub utara dengan diberi lambang C, kota Makkah (Ka'bah) diberi simbul A, dan Ponorogo diberi simbul B (B inilah yang dicari). Dengan demikian tiga titik tersebut membentuk segi tiga bola, meridian yang melalui Ponorogo diberi simbul a, sedangkan busur yang menghubungkan Ka'bah diberi simbul c.

\section{Gambar: 1.1}

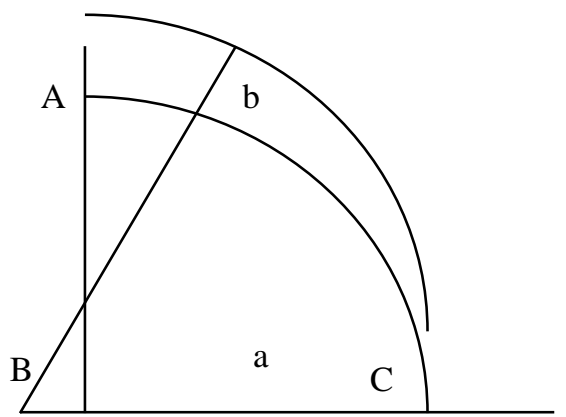

Ketrangan:

B: Sudut (azimut kiblat yang dicari)

Rumus: $\operatorname{Cotg} B=\operatorname{Cotg} b . \operatorname{Sin} a: \operatorname{Sin} c-\operatorname{Cos} a \cdot \operatorname{Cotg} c$

10 Umar Salim, Panduan Ilmu Falak, 9. 
Aro Qodam Arrasyid \& Kadenun, Perhitungan Arah Kiblat Masjid Menggunakan ... 207

Keterangan: (1) Sisi a (90-lintang tempat ). (2) Sisi b (90-lintang Makkah). (3) Sudut C (bujur tempat-bujur Makkah)

\section{HIKMAH MENGHADAP KIBLAT}

Al-Imam Fakhr al-Razi menyebutkan hikmah dialihkan kiblat ke Masjidil Haram sebagai berikut:

1. Bahwa sesungguhnya seorang hamba yang dha'if apabila menghadap ke masjlis raja yang agung, tentu ia akan menghadap kepadanya dengan menghadapkan mukanya dan tidak akan berpaling darinya, menyampaikan kata-kata pujian kepadanya, merendahkan diri kepadanya dan berkhidmat untuknya. Oleh karenanya, hakikat menghadap kiblat adalah sebagai halnya menghadap kepada raja, tidak berpaling dari padanya, bacaan-bacaan dan tasbih-tasbih sebagai kata-kata pujian, sedang ruku' dan sujud adalah sebagai pencerminan berkidmat kepadanya.

2. Bahwa sesungguhnya Allah Swt. menyukai kelembutan hati di antara sesama mukmin. Maka kalau seandainya masing-masing orang menghadap ke arah yang berbeda-beda tentu hal itu akan tampak sekali perbedaan mereka, sehingga Allah menentukan satu arah dan menyuruh kaum muslimin seluruhnya menghadap ke arah ini agar terwujud kesatuan mereka.

3. Bahwa sesungguhnya Allah Swt., mengistimewakan Ka'bah dengan menyandarkan kepada-Nya. Sebagaimana firman-Nya: Dan sucikanlah rumah-KU (QS. al-Hajj; 22: 26).

Dengan demikian, hikmahnya kita menghadap ke kiblat, yaitu jihah yang telah dipilih oleh Allah Swt. dalam 
mempersembahkan darma bakti hamba kepada Khaliknya. Bukan jasmani yang kita hadapkan ke jihah, tetapi pada batinnya, hati kitalah yang kita hadapkan ke hadirat yang Maha Kuasa. ${ }^{11}$

\section{ARAH KIBLAT MASJID ZAHRA FATMA, MASJID AL-FALAH, DAN MASJID BAITUL MUTTAQIN SEBELUM MENGGUNAKAN THEODOLIT}

Dari hasil wawancara dengan Bapak Djuremi selaku takmir masjid, beliau mengatakan bahwa masjid Fatma Zahra telah dilakukan pengkiblatan oleh Mbah Munir sebagai pengasuh Ponpes Subulul Huda Kembang Sawit Kebonsari Madiun. ${ }^{12}$ Penulis melakukan pengecekan arah kiblat di masjid tersebut ialah dengan lintang - $7^{0} 43^{\prime}$ dan bujur $111^{0} 30^{\prime}$, sehingga diketahui arah kiblat masjid tersebut yaitu: $61^{0} 05^{\prime} 11.28$ " dari arah Utara ke Barat, dan atau $28^{0} 54^{\prime} 48.72^{\prime \prime}$ dari arah Barat ke Utara.

Dari hasil wawancara penulis dengan Bapak Ghozali mengatakan bahwa orang yang mengkiblat masjid al-Falah ini, dulunya itu juga dari pihak Depag, tetapi waktu itu alat yang dipakai untuk mengukur kiblat masih tergolong merupakan alat yang sederhana pada waktu itu. Oleh karenanya, penulis melakukan pengecekan ulang mengenai arah kiblat di masjid tersebut yaitu dengan lintang $-07^{\circ} 29^{\prime}$ dan bujur $111^{0} 29^{\prime}$ kiblat

11 Evi Dahliyatin Nuroini, "Pengaruh Pergeseran Lempeng Bumi terhadap Penentuan Arah Kiblat Masjid-masjid di Kota Yogyakarta", Skripsi UIN Maulana Malik Ibrahim, 2010, 41.

12 Djuremi, "Wawancara”, Madiun: 10 juni 2016. 
Aro Qodam Arrasyid \& Kadenun, Perhitungan Arah Kiblat Masjid Menggunakan ... 209 masjid tersebut adalah: $67^{\circ} 09^{\prime} 42.34^{\prime \prime}$ dari arah Utara ke Barat, dan atau $22^{0} 50^{\prime} 17.66^{\prime \prime}$ dari arah Barat ke Utara. ${ }^{13}$

Dari hasil wawancara penulis dengan takmir masjid Baitul Muttaqin bahwa masjid tersebut, dulunya juga telah dikiblat oleh seorang mudin pada waktu itu. Penulis melakukan pengecekan arah kiblat di masjid tersebut yaitu dengan lintang $-07^{0} 43^{\prime}$ dan bujur $111^{\circ} 30^{\prime}$, diketahui kiblat masjid tersebut adalah: 70 57' 35.00" dari arah Utara ke Barat, dan atau $19^{\circ} 02^{\prime} 25.00^{\prime \prime}$ dari Barat ke Utara. ${ }^{14}$

\section{ARAH KIBLAT MASJID FATMA ZAHRA, MASJID AL-FALAH, DAN MASJID BAITUL MUTTAQIN SETELAH MENGGUNAKAN THEODOLIT}

1. Masjid Fatma Zahra

Keterangan :

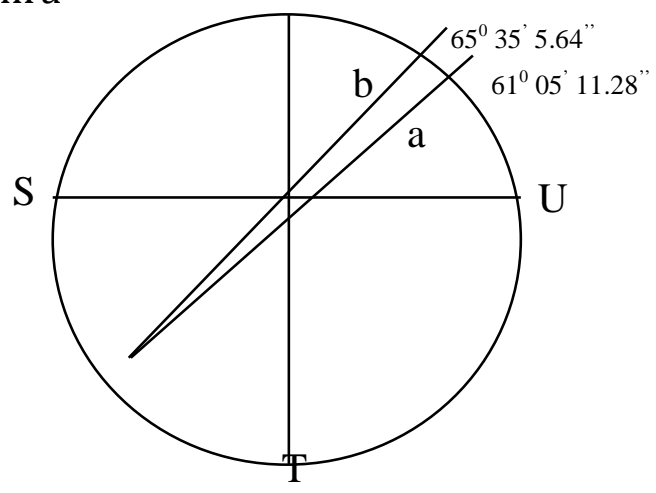

a: Arah kiblat asli masjid Fatma Zahra.

b: Arah kiblat setelah dilakukan pengecekan menggunakan alat theodolit.

13 Imam Ghozali, "Wawancara”, Madiun: 11 juni 2016.

14 Shoim, "Wawancara", Madiun: 22 juni 2016. 
Penulis menganalisis arah kiblat masjid Fatma Zahra saat ini kurang akurat, karena pada waktu pengkiblatan masjid tersebut masih menggunakan alat yang sederhana, penulis sedikit kaget dan terkejut, karena arah kiblat masjid adalah kurang ke Selatan sebesar $4^{0} 2^{\prime} 9^{\prime} 54.36^{\prime \prime}$, hal ini terjadi setelah dilakukan pengecekan ulang dengan menggunakaan data ephemeris dengan theodolit.

Metode azimut kiblat menggunakan data ephemeeris dengan theodolit adalah metode yang digunakan oleh Departemen Agama RI dan hasil perhitungannya diakui kebenarannya dan theodolit adalah alat yang terjamin keakurasiannya, karena datadata perhitungan tersebut diolah secara mekanik. Data ephemeris menggunakan data dari winhisab untuk mencari equition of time dan deklinasi yang selalu berubah setiap jam walaupun pada jam tertentu memiliki nilai yang sama, sehingga lebih akurat data yang diperoleh. Adapun langkah-langkah perhitungan azimut kiblat menggunkan data ephemeris dengan theodolit yang digunakan penulis ketika melakukan pengecekan arah kiblat di masjid tersebut pada jam 16.48 WIB.

Penulis melakukan pengecekan posisi matahari di jalur Ka'bah pada jam 16.48 WIB dengan menggunakan alat theodolit untuk mengetahui arah kiblat masjid tersebut. Setelah dilakukannya pengecekan tersebut diperoleh data kiblat masjid Fatma Zahra kurang ke Selatan dengan rincian untuk kiblat asli $61^{0}$ 05' 11.28" dari arah Utara ke Barat dengan kiblat hasil penelitian penulis $65^{\circ} 35^{\prime} 5.64^{\prime \prime}$ dari arah Utara ke Barat. 


\section{Di Masjid al-Falah}

Keterangan:

a: Arah kiblat asli Masjid al-Falah.

b: Arah kiblat setelah dilakukan pengecekan dengan alat theodolit.



Penulis menganalisis arah kiblat masjid al-Falah saat ini kurang akurat, karena pada waktu pengkiblatan masjid tersebut masih menggunakan alat yang sederhana, penulis kaget dan terkejut, karena arah kiblat masjidnya kurang ke Utara sebesar $1^{0}$ $35^{\prime} 21.17 "$ setelah dilakukan pengecekan dengan menggunakaan data ephemeris dengan theodolit.

Metode azimut kiblat yang menggunakan data ephemeeris dengan theodolit adalah metode yang digunakan oleh Departemen Agama RI dan hasil perhitungannya diakui kebenarannya dan theodolit adalah alat yang terjamin keakurasiannya, karena datadata perhitungan diolah secara mekanik. 
Data ephemeris dengan menggunakan data dari winhisab untuk mencari equition of time dan deklinasi yang selalu berubah setiap jam walaupun pada jam tertentu memiliki nilai yang sama, sehingga lebih akurat data yang diperoleh. Adapun langkahlangkah perhitungan azimut kiblat menggunakan data ephemeris dengan theodolit yang digunakan penulis ketika melakukan pengecekan arah kiblat di masjid al-Falah pada jam 15.05 WIB. Penulis melakukan pengecekan posisi matahari dijalur Ka'bah pada jam 15.05 WIB dengan menggunakan alat theodolit untuk mengetahui arah kiblat di masjid tersebut. Setelah dilakukannya pengecekan tersebut diperoleh data kiblat di masjid tersebut kurang ke Utara dengan rincian untuk kiblat asli $67^{\circ} 09^{\prime} 42.34$ " dari arah Utara ke Barat, sedangkan kiblat hasil penelitian penulis yaitu $65^{\circ} 34^{\prime} 21.17^{\prime \prime}$ dari arah Utara ke Barat.

3. Masjid Baitul Muttaqin

Keterangan :

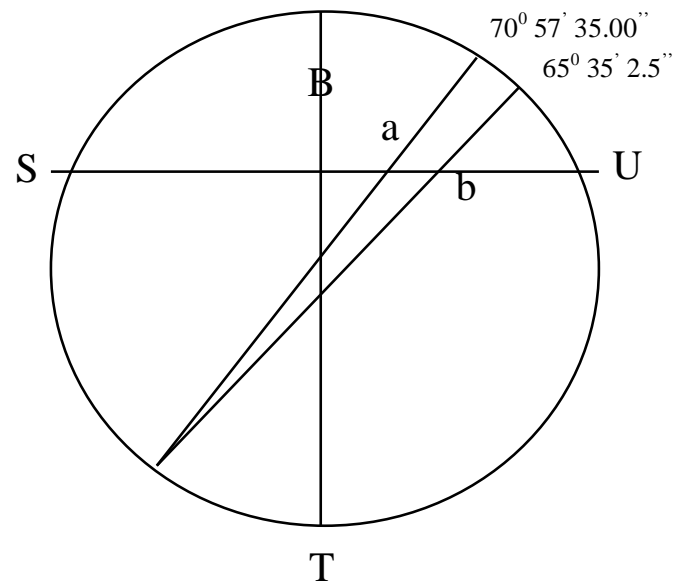

a: Arah kiblat asli masjid baitul Muttaqin.

b: Arah kiblat setelah dilakukan pengecekan dengan alat theodolit. 
Aro Qodam Arrasyid \& Kadenun, Perhitungan Arah Kiblat Masjid Menggunakan ... 213

Penulis menganalisis arah kiblat di masjid Baitul Muttaqin saat ini kurang akurat, karena pada waktu pengkiblatan masjid tersebut masih menggunakan alat yang sederhana, sehingga arah kiblat masjid tersebut kurang ke Utara sebesar: $5^{0} 22^{\prime} 32.5^{\prime \prime}$ setelah dilakukan pengecekan menggunakaan data ephemeris dengan theodolit.

Metode azimut kiblat menggunakan data ephemeeris dengan theodolit adalah metode yang digunakan oleh Departemen Agama RI dan hasil perhitungannya diakui kebenarannya dan theodolit adalah alat yang terjamin keakurasiannya, karena datadata perhitungan diolah secara mekanik. Data ephemeris menggunakan data dari winhisab untuk mencari equition of time dan deklinasi yang selalu berubah setiap jam walaupun pada jam tertentu memiliki nilai yang sama, sehingga lebih akurat data yang diperoleh. Adapun langkah-langkah perhitungan azimut kiblat menggunkan data ephemeris dengan theodolit yang digunakan penulis ketika melakukan pengecekan arah kiblat masjid Baitul Muttaqin yaitu pada jam 16.14 WIB.

Penulis melakukan pengecekan posisi matahari di jalur Ka'bah pada jam 16.48 WIB dengan menggunakan alat theodolit untuk mengetahui arah kiblat masjid tersebut. Setelah dilakukannya pengecekan, diperoleh data kiblat masjid Baitul Muttaqin kurang ke utara dengan rincian untuk kiblat asli ialah: $70^{0} 57^{\prime} 35.00$ ", sedangkan untuk kiblat hasil penelitian penulis ialah: $65^{0} 35^{\prime} 2.5^{\prime \prime}$. 
Berdasarkan hasil penelitian tentang penentuan arah kiblat masjid Fatma Zahra, masjid al-Falah, dan masjid Baitul Muttaqin Kebonsari madiun, maka penulis menyimpulkan sebagai berikut: Arah kiblat masjid Fatma Zahra, masjid al-Falah, dan masjid Baitul Muttaqin sebelum menggunakan alat theodolit yaitu: Arah kiblat masjid Fatma Zahra ialah: $61^{0} 05^{\prime} 11.28^{\prime \prime}$ dari arah Utara ke Barat, arah kiblat masjid al-Falah ialah: 670 09' 43.34" dari arah Utara ke Barat, dan arah kiblat masjid Baitul Muttaqin ialah: 70 57' 35.00" dari arah Barat ke Utara. Adapun arah kiblat masjid Fatma Zahra, masjid al-Falah, dan masjid Baitul Muttaqin setelah menggunakan alat theodolit ialah: Arah kiblat masjid Fatma Zahra adalah: $65^{\circ} 35^{\prime}$ 5.64" dari Utara ke Barat, yaitu selisih: 40 29' 54.36" dengan kiblat aslinya, arah kiblat masjid al-Falah ialah: $65^{0} 34^{\prime} 21.17^{\prime \prime}$ dari Utara ke Barat, yaitu selisih: $1^{0} 35^{\prime} 21.17^{\prime \prime}$ dengan kiblat aslinya, dan arah kiblat masjid Baitul Muttaqin ialah: $65^{\circ} 35^{\prime} 2.5^{\prime \prime}$ dari Utara ke Barat, yaitu selisih: $5^{0} 22^{\prime} 32.5^{\prime \prime}$ dengan kiblat aslinya.

\section{DAFTAR PUSTAKA}

Al-Bukhari, Abu Abdillah Muhammad bin Ismail. Shahih Bukhari. Beirut: Dar Al-Fikr.

Ali, M. Sayuthi. Ilmu Falak I. Jakarta: Raja Grafindo, 1997.

Al-Manawi. at-Taufik 'ala Muhimmat at-Ta'arif . Damaskus: Dar alFikr, 1410.

Depag RI. al-Qur'an dan Terjemahnya. Semarang: Lajnah Pentashih Mushaf al-Qur'an, 1992.

Djuremi. "Wawancara". Madiun: 10 juni 2016.

Faridi. "Penerapan Algoritma Jean Meus dalam Pengukuran Arah Kiblat Dengan Theodolit". Tesis UIN Sunan Kalijaga, 2012. Ghozali, Imam. "Wawancara”. Madiun: 11 juni 2016. 
Aro Qodam Arrasyid \& Kadenun, Perhitungan Arah Kiblat Masjid Menggunakan ... 215

Hambali, Slamet. "Penentuan Awal Waktu Shalat dan Arah Kiblat Seluruh Dunia". Semarang: Progam Pasca Sarjana IAIN Walisongo Semarang, 2001.

Jamil, A. Ilmu Falak Teori dan Aplikasi. Jakarta: Amzah, 2009.

Khazin, Muhyidin. Ilmu Falak dalam Teori dan Praktik. Yogyakarta: Buana Pustaka, 1998.

Mas'ud, Ibnu dan Abidin, Zainal. Fiqh Madzhab Syafi'i. Bandung: CV Pustaka Setia, 2000.

Murtadho, Muhammad. Ilmu Falak Praktis. Malang: UIN Malang, 2008.

Nuroini, Evi Dahniyatin. "Pengaruh Pergeseran Lempeng Bumi terhadap Penentuan Arah Kiblat Masjid-masjid di Kota Yogyakarta". Skrepsi UIN Maulana Malik Ibrahim, 2010.

Salim, Umar. Panduan Ilmu Falak. Ponorogo: Madrasah Miftahul Huda Mayak, 2013.

Shoim. "Wawancara”. Madiun: 22 juni 2016.

Tarjih, Tim Majelis dan Muhammadiyah, Tajdid PP., Pedoman Hisab Muhammadiyah, Yogyakarta: Majelis Tarjih dan Tajdid PP Muhammadiyah, 2009. 